Зубик Л. В., к.пед.н., доцент (Національний університет водного господарства та природокористування, м. Рівне)

\title{
УДОСКОНАЛЕННЯ ІНСТРУМЕНТІВ ЕФЕКТИВНОГО ЕКОНОМІЧНОГО МОНІТОРИНГУ
}

Запропоновано інструменти автоматизації проведення розрахунків прогнозування ймовірності розвитку підприємств з використанням сучасних систем програмування.

Ключові слова: динаміка розвитку підприємств, комп'ютерне моделювання, економічний моніторинг, прогнозування.

Постановка проблеми. У практиці розвитку країн із ринковою економікою банкрутство виступає як механізм регулювання та саморегулювання економіки. Банкрутство характеризує неспроможність підприємства задовольнити вимоги кредиторів щодо сплати за товари, роботи та послуги, а також забезпечити обов'язкові платежі в бюджет і позабюджетні фонди. Банкрутство підприємств $є$ суттєвою проблемою економіки України. В умовах вітчизняної економіки банкрутству властивий масовий характер, тому неплатоспроможність пов'язана не лише з окремими підприємствами, але й поширюється на регіон та країну в цілому. Це пояснюється особливостями української економіки, зокрема тривалим періодом функціонування підприємств у середовищі адміністративної економіки, великою питомою вагою в економіці підприємств-гігантів, високим відсотком морального і фізичного зносу основних фондів на підприємствах. Світова економічна криза, нестабільність економічного і політичного середовища в країні, недосконалість правового та податкового законодавства привели до збільшення кількості неплатоспроможних підприємств, які прямують до банкрутства, що у більшості випадків призводить до їх ліквідації. Таким чином, аналіз ймовірності банкрутства і підтримки платоспроможності підприємства $€$ досить актуальними питаннями.

Аналіз останніх досліджень і публікацій. Дослідженням ймовірності банкрутства підприємств приділяється значна увага серед вітчизняних і зарубіжних науковців. Розробкою методик і критеріїв прогнозування банкрутства займалися свого часу такі відомі вчені, як Е. Альтман, Р. Ліс, А. Таффлер. Питання оцінки банкрутства розглядали О. Базілінська [1], Ф. Бутинець [2], А. Поддєрьогін [3], В. По- 
дольська [4] та інші вчені. Якісна оцінка вірогідності появи негативних явищ з метою прогнозування і попередження потенційної загрози банкрутства на рівні підприємства $є$ єдино можливим і ефективним способом запобігання соціально-економічних криз. Дослідження наявних методик діагностики банкрутства дозволяють відзначити, що жоден із діючих варіантів не забезпечує точний результат. Зусилля, що витрачаються на запобігання банкрутству, часом виявляються не достатньо ефективними. Крім того, вони самі провокують кризові процеси, базуючись на свідомо недійсній основі.

Метою дослідження $€$ розробка програмного комплексу, що дозволяє автоматизувати процес прогнозування ймовірності банкрутства підприємств.

Виклад основного матеріалу. Згідно діючого законодавства, «Банкрутство - визнана арбітражним судом неспроможність боржника відновити свою платоспроможність та задовольнити визнані судом вимоги кредиторів не інакше як через застосування ліквідаційної процедури» [5]. Підприємство до стану банкрутства може призвести погіршення тих показників, що визначають його фінансову стійкість. Тому саме на них базується аналіз ймовірності досягнення такого стану.

Причинами виникнення банкрутства підприємства можуть бути: дефіцит власних оборотних активів, недосконалість механізму ціноутворення, бездіяльність юридичних служб підприємства, відсутність контролю за договірними відносинами, зростання дебіторської та кредиторської заборгованості, неефективне використання ресурсів, перевищення темпів росту витрат над темпами росту виручки від реалізації та ін.

Класифікують наступні види банкрутства:

- реальне (нездатність підприємства відновити свою фінансову стабільність через втрату капіталу);

- технічне (неплатоспроможність підприємства, викликана простроченням його дебіторської заборгованості);

- фіктивне (неправдиве оголошення підприємства банкрутом 3 метою отримання відстрочки платежів);

- навмисне (штучно створена неплатоспроможність підприємства) $[6$, С. 73].

Методи досліджень. Аналіз ймовірності банкрутства підприємства включає в себе низку взаємопов'язаних етапів. Р. Квасницька пропонує застосовувати підприємствам в системі антикризового управління наступну послідовність діагностики банкрутства:

- аналіз ранніх ознак кризового стану підприємства;

- економічна оцінка та аналіз бухгалтерського балансу підпри- 
ємства;

- аналіз фінансового стану підприємства за групами коефіцієнтів, які характеризують майновий стан, ліквідність та платоспроможність, фінансову стійкість, ділову активність та рентабельність діяльності;

- діагностика на основі рейтингового оцінювання;

- дискримінантний аналіз (моделі Е. Альтмана, У.Бівера, М. Гольдера, Ж. Конана, Р. Ліса, Г. Спрінгейта, Дж. Таффлера, Г. Тішоу, Дж. Фулмера та інші).

Згідно з запропонованою етапністю діагностики ймовірності банкрутства, першим їі етапом є аналіз ранніх ознак кризового стану підприємства. Для цього можна скористатися методом Скоуна, який шукає відповіді на ряд питань, а саме: чи компанії менше п'яти років; чи компанія переїжджає або має намір переїхати; чи не змінила компанія останнім часом банк, аудиторів, директорів. Якщо відповідь на більшість таких питань є позитивною, то фінансовий стан підприємства вважається важким.

На наступному етапі проводиться аналіз бухгалтерського балансу підприємства, під час якого здійснюється економічна оцінка його структури, динаміки майна, джерел утворення. Це дозволяє встановити поточну оцінку фінансового стану підприємства та описати динаміку його розвитку.

Черговий етап передбачає проведення аналізу фінансового стану підприємства, тобто розрахунок фінансових коефіцієнтів та порівняння їх фактичних значень з нормативними. Метод потребує лише інформації фінансової звітності. Проте аналізу фінансового стану підприємства для визначення ймовірності банкрутства також не достатньо.

Одним з важливих етапів діагностики банкрутства є формування рейтингової оцінки. Цей вид діагностики базується на встановленні переліку ключових індикаторів та їх порівнянні з нормативними критеріальними значеннями для ідентифікації стану об'єкта в оперативному режимі. Підприємство відносять до відповідного класу загрози банкрутства на підставі області значення ключового показника. Досліджуючи діяльність підприємств, різні науковці пропонують для діагностики інші показники. Кожне підприємство має можливість формувати дану систему показників самостійно.

Суть дискримінантного аналізу полягає у побудові функції та обчисленні інтегрального показника, на підставі якого 3 певною ймовірністю можна передбачити банкрутство підприємства, використовуючи статистично-математичні методи. У дискримінантному 
аналізі використовуються моделі Е. Альтмана, У. Бівера, Г. Спрінгейта, Дж. Таффлера, Г. Тішоу.

Розглянутий підхід послідовності діагностики банкрутства реалізується з використанням різноманітних методів, які $€$ широко застосовуваними за кордоном, але не завжди можуть бути прийнятними для сучасного вітчизняного підприємства. Це вказує на необхідність подальшого дослідження даної теми з метою розробки підходів до адаптації існуючих зарубіжних методів діагностики банкрутства до сучасних вітчизняних умов господарювання. В Україні кожне підприємство має змогу розробляти дискримінантну модель самостійно, виходячи із умов його функціонування.

Вітчизняні економісти використовують різні підходи до визначення банкрутства: нездатність підприємства фінансувати поточну діяльність і погашати свої зобов'язання; фінансова неспроможність підприємства, що виявляється у перевищенні витрат на виробництво продукції над виручкою від її реалізації. Для оцінювання ймовірності банкрутства підприємства достатньо побудувати певний інтегральний показник, який би включав в себе найважливіші характеристики фінансової стійкості. Для досягнення мети можна рекомендувати такий набір показників фінансової стійкості підприємства:

- рентабельність капіталу за "чистим прибутком";

- рентабельність продукції;

- оборотність коштів, вкладених в оборотні активи;

- коефіцієнт фінансової незалежності;

- ліквідність (коефіцієнт покриття поточних пасивів).

За основу розрахунку інтегрального показника береться порівняння кожного з перелічених параметрів за достатньо тривалий період роботи підприємства з найвищими досягненнями підприємства за цими параметрами протягом аналізованого періоду. Такий прийом дає змогу проаналізувати у динаміці фінансову стійкість підприємства й оцінити її з точки зору відхилення фактичних результатів від максимальних, досягнутих у минулі періоди. Оскільки найбільш широке застосування серед методів прогнозування банкрутства за деякими оцінками належить багатофакторній моделі Альтмана, саме вона була виокремлена для реалізації у тестовому прикладі.

Тестовий приклад прогнозування ймовірності банкрутства за п'ятифакторною моделлю Альтмана базується на показниках, наведених в табл. 1, де відображена методика їх розрахунку.

Економічна інформація $є$ різновидом управлінської інформації, а використання сучасної інформаційної бази неможливе без комп'ютера. Цінність і своєчасність управлінського рішення значною мірою залежить від можливості вчасно зібрати, проаналізувати та ін- 
терпретувати інформацію. Прийняття управлінських рішень тісно пов'язане з постійним перетворенням інформації, а процесу управління притаманний інформаційний характер. Автоматизація визначення ймовірності банкрутства підприємств може бути здійснена за допомогою запропонованого програмного комплексу, реалізованого в середовищі Microsoft Visual Basic.

Таблиця 1

Тестовий приклад прогнозування ймовірності банкрутства за моделлю Альтмана

\begin{tabular}{|c|c|}
\hline Показники & Методика розрахунку \\
\hline $\begin{array}{l}\text { Частка власних оборотних кош- } \\
\text { тів в активах (XI) }\end{array}$ & $\begin{array}{l}\text { Власний оборотний капітал/ Зага- } \\
\text { льна вартість активів }\end{array}$ \\
\hline $\begin{array}{l}\text { Рентабельність активів, розра- } \\
\text { хована з використанням нероз- } \\
\text { поділеного прибутку }(X 2)\end{array}$ & $\begin{array}{l}\text { Нерозподілений прибуток/ Зага- } \\
\text { льна вартість активів }\end{array}$ \\
\hline $\begin{array}{l}\text { Рентабельність активів, розра- } \\
\text { хована з використанням чистого } \\
\text { прибутку (ХЗ) }\end{array}$ & $\begin{array}{l}\text { Прибуток до виплати відсотків/ } \\
\text { Загальна вартість активів }\end{array}$ \\
\hline $\begin{array}{l}\text { Коефіцієнт покриття поточних } \\
\text { зобов'язань власним капіталом } \\
(X 4)\end{array}$ & $\begin{array}{l}\text { Власний капітал (ринкова вар- } \\
\text { тість)/ Поточні зобов'язання }\end{array}$ \\
\hline Коефіцієнт трансформації (X5) & $\begin{array}{l}\text { Чиста виручка/ Загальна вартість } \\
\text { активів }\end{array}$ \\
\hline Результуючий показник & $\begin{array}{l}Z=1,2 \times 1+1,4 \times 2++3,3 \times 3+0,6 \times 4+ \\
1,0 \times 5\end{array}$ \\
\hline
\end{tabular}

Економічна інформація $є$ різновидом управлінської інформації, а використання сучасної інформаційної бази неможливе без комп'ютера. Цінність і своєчасність управлінського рішення значною мірою залежить від можливості вчасно зібрати, проаналізувати та інтерпретувати інформацію. Прийняття управлінських рішень тісно пов'язане з постійним перетворенням інформації, а процесу управління притаманний інформаційний характер. Автоматизація визначення ймовірності банкрутства підприємств може бути здійснена за допомогою запропонованого програмного комплексу, реалізованого в середовищі Microsoft Visual Basic.

На рис. 1 наведено меню програми, де обирається модель оцінки ймовірності банкрутства підприємства. 


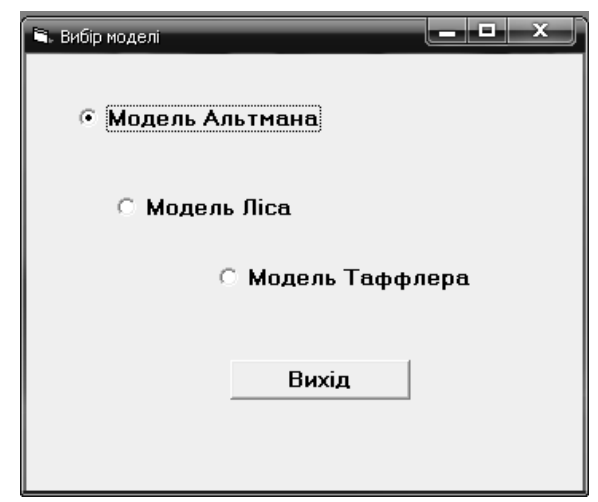

Рис. 1. Вибір моделі для аналізу

На рис. 2 наведено результати роботи програмної реалізації моделі Альтмана для оцінки ймовірності банкрутства підприємства.

Результати проведених розрахунків підтверджують, що у звітному періоді отримані на підприємстві значення коефіцієнтів нижчі за оптимальні. Це означає, що воно не забезпечене власним оборотним капіталом і не має достатньо поточних активів для покриття власних короткострокових зобов'язань, а отже, має реальну можливість до втрати платоспроможності.

Висновки. У роботі розглянуто варіанти автоматизації проведення розрахунків для прогнозування ймовірності розвитку підприємств. Запропонований програмний комплекс дозволяє зменшити тривалість проведення розрахунків, знизити ймовірність допущення помилок, підвищити оперативність та ефективність прийняття управлінських рішень.

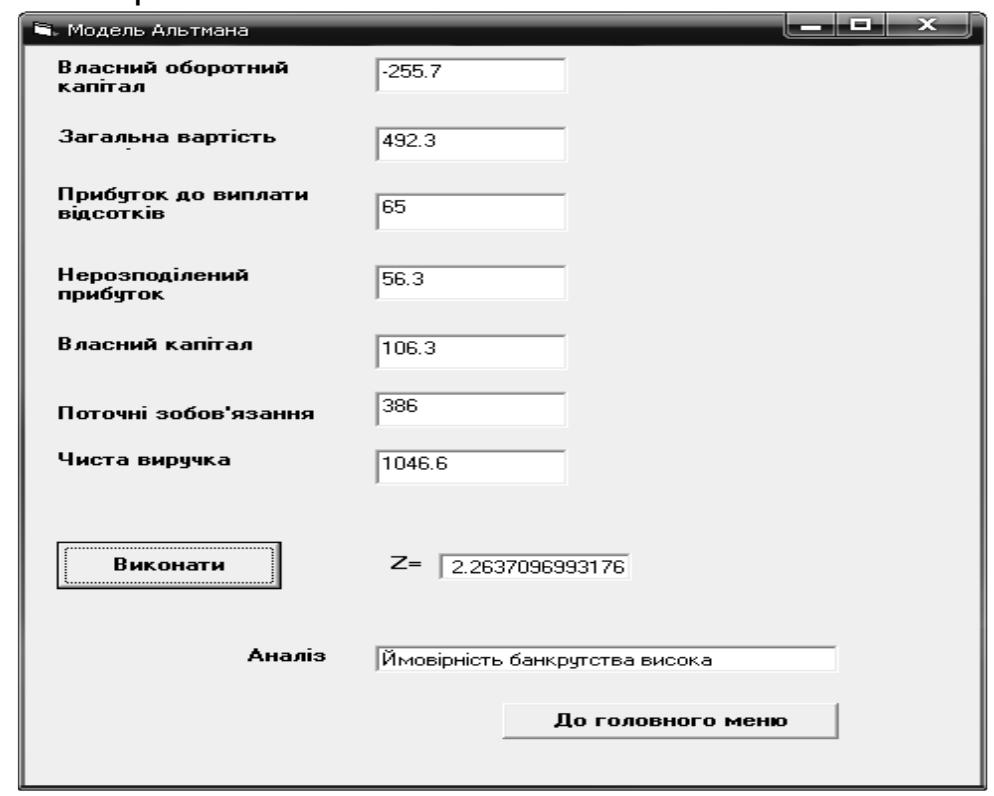

Рис. 2. Програмна реалізація моделі Альтмана 
1. Базілінська О. Я. Фінансовий аналіз: теорія та практика : навч. посіб. ЦУЛ, 2009. 328 с. 2. Бутинець Ф. Ф. Економічний аналіз : навч. посіб. Житомир : ПП «Рута», 2003. 680 с. 3. Фінанси підприємств : підручник / Поддєрьогін А. М. та ін. 5-те вид., перероб. та допов. К. : КНЕУ, 2005. 546 с. 4. Подольська В. О. Прогнозування можливого банкрутства підприємства : текст лекцій. Полтава : РВВ ПУСКУ, 2002. 75 с. 5. Про відновлення платоспроможності боржника або визнання його банкрутом : Закон України від 30.06.1999 р. із змінами і доповненнями. URL: http://zakon3.rada.gov.ua/laws/show/784-14 (дата звернення : 03.10.2018). 6. Методика проведення поглибленого аналізу фінансово-господарського стану підприємств і організацій, затверджена наказом Агентства з питань запобігання банкрутству підприємств та організацій від 21.03.1997 р., № 37. URL: http://zakon2.rada.gov.ua/laws/show/z0288-97 (дата звернення : 03.10.2018). 7. Методичні рекомендації щодо виявлення ознак неплатоспроможності підприємства та ознак з приховування банкрутства, фіктивного банкрутства чи доведення до банкрутства, затверджені Наказом Міністерства економіки України від 17 січня 2001 року № 10. URL: http://search.ligazakon.ua/l_doc2.nsf/link1/ed_2001_01_17/ME01007.html (дата звернення : 03.10.2018). 8. Салига С. Я. Антикризове фінансове управління підприємством : навч. посіб. К. : Центр учбової літератури, 2005. 208 с. 9. Фучеджи В. І. Характеристика методів та моделей діагностики кризового стану підприємства. Вісник Національного університету «Львівська політехніка». Менеджмент та підприємництво в Україні: етапи становлення і проблеми розвитку / відп. редактор О. Є. Кузьмін. Львів : Вид-во Львівської політехніки, 2010. № 691. С. 240-245.

\section{REFERENCES :}

1. Bazilinska O. Ya. Finansovyi analiz: teoriia ta praktyka : navch. posib. TsUL, 2009. 328 s. 2. Butynets F. F. Ekonomichnyi analiz : navch. posib. Zhytomyr: PP «Ruta», 2003. 680 s. 3. Finansy pidpryiemstv : pidruchnyk / Poddierohin A. M. ta in. 5-te vyd., pererob. ta dopov. K. : KNEU, 2005. 546 s. 4. Podolska V. 0. Prohnozuvannia mozhlyvoho bankrutstva pidpryiemstva : tekst lektsii. Poltava : RVV PUSKU, 2002. 75 s. 5. Pro vidnovlennia platospromozhnosti borzhnyka abo vyznannia yoho bankrutom : Zakon Ukrainy vid 30.06.1999 r. iz zminamy i dopovnenniamy. URL: http://zakon3.rada.gov.ua/laws/show/784-14 (data zvernennia : 03.10.2018). 6. Metodyka provedennia pohlyblenoho analizu finansovo-hospodarskoho stanu pidpryiemstv i orhanizatsii, zatverdzhena nakazom Ahentstva z pytan zapobihannia bankrutstvu pidpryiemstv ta $\begin{array}{llllll}\text { orhanizatsii vid } & \text { 21.03.1997 } & \text {., } & \text { № } & \text { URL: }\end{array}$ http://zakon2.rada.gov.ua/laws/show/z0288-97 (data zvernennia : 03.10.2018). 7. Metodychni rekomendatsii shchodo vyiavlennia oznak neplatospromozhnosti pidpryiemstva ta oznak z prykhovuvannia bankrutstva, fiktyvnoho bankrutstva chy dovedennia do bankrutstva, zatverdzheni Nakazom Mini-sterstva ekonomiky Ukrainy vid 17 sichnia 2001 roku № 10 . URL: 
http://search.ligazakon.ua/l_doc2.nsf/link1/ed_2001_01_17/ME01007.html (data zvernennia : 03.10.2018). 8. Salyha S. Ya. Antykryzove finansove upravlinnia pidpryiemstvom : navch. posib. K. : Tsentr uchbovoi literatury, 2005. 208 s. 9. Fuchedzhy V. I. Kharakterystyka metodiv ta modelei diahnostyky kryzovoho stanu pidpryiemstva. Visnyk Natsionalnoho universytetu «Lvivska politekhnika». Menedzhment ta pidpryiemnytstvo v Ukraini: etapy stanovlennia i problemy rozvytku / vidp. redaktor 0. Ye. Kuzmin. Lviv : Vyd-vo Lvivskoi politekhniky, 2010. № 691. S. 240-245.

Рецензент: д.е.н., професор Савіна Н. Б. (НУВГП)

Zubyk L. V., Candidate of Pedagogic Sciences (Ph.D.), Associate Professor (National University of Water and Environmental Engineering, Rivne)

\section{IMPROVEMENT OF INSTRUMENTS FOR EFFECTIVE ECONOMIC MONITORING}

The tools of automation of calculations for forecasting the probability of development of enterprises with the use of modern programming systems were proposed.

Keywords: the dynamics of enterprise development, computer simulation, economic monitoring, forecasting.

Зубик Л. В., к.пед.н., доцент (Национальный университет водного хозяйства и природопользования, г. Ровно)

\section{СОВЕРШЕНСТВОВАНИЕ ИНСТРУМЕНТОВ ЭФФЕКТИВНОГО ЭКОНОМИЧЕСКОГО МОНИТОРИНГА}

Предложены инструменты автоматизации проведения расчетов прогнозирования вероятности развития предприятий с использованием современных систем программирования.

Ключевые слова: динамика развития предприятий, компьютерное моделирование, экономический мониторинг, прогнозирование. 